\title{
Effectivity of BS4 Enzyme Complex on the Performance of Laying Hens Fed with Different Ingredients
}

\author{
Sinurat AP, Purwadaria T, Haryati T \\ ${ }^{I}$ Indonesian Research Institute for Animal Production, PO Box 221, Bogor 16002, Indonesia \\ E-mail:ap_sinurat@litbang.pertanian.go.id \\ (received 06-01-2016; revised 21-03-2016; accepted 29-03-2016)
}

\begin{abstract}
ABSTRAK
Sinurat AP, Purwadaria T, Haryati T. 2016. Pengujian efektifitas enzim BS4 terhadap performan ayam petelur yang diberi jenis bahan pakan yang berbeda. JITV 21(1): 1-8. DOI: http://dx.doi.org/10.14334/jitv.v21i1.1389

Penelitian dilakukan untuk menguji efektifitas enzim BS4 yang dihasilkan dengan pembiakan Eupenicilium javanicum terhadap performan ayam petelur yang diberi jenis pakan yang berbeda. Tiga ransum dengan kandungan gizi yang sama (protein kasar, ME, lysine tercerna, methionine + cystine tercerna, tryptophan tercerna, $\mathrm{Ca}$ and $\mathrm{P}$ tersedia) disusun sesuai dengan kebutuhan ayam petelur. Ketiga ransum tersebut mengandung 3 bahan pakan utaman yang berbeda yaitu jagung dan bungkil kedelai (kontrol), dedak 30\% atau bungkil inti sawit (BIS) 20\%. Ketiga ransum kemudian ada yang ditambahkan enzim BS4 dan ada yang tidak. Setiap ransum diberikan kepada 24 ekor (6 ulangan @ 4 ekor) ayam Isa Brown mulai umur 19 hingga 37 minggu dan diamati performannya. Data dianalisa secara statistik dengan rancangan faktorial 2 (enzymes) X 3 (bahan pakan). Hasil menunjukkan bahwa penambahan multi enzim BS4 kedalam ransum ayam petelur tidak mempengaruhi perubahan bobot badan, konsumsi pakan, mortalitas, berat telur dan tebal kerabang telur. Suplementasi enzim BS4 kedalam ransum ayam petelur nyata meningkatkan produksi telur $(\mathrm{P}<0.05)$ dan memperbaiki FCR $(\mathrm{P}<0.01)$, pada ketiga jenis bahan pakan yang diuji (jagung, dedak dan BIS). Penambahan enzim BS4 juga nyata meningkatkan warna kuning telur pada ransum yang mengandung $20 \%$ BIS. Ayam yang diberi BIS $20 \%$ menghasilkan telur yang lebih banyak dibandingkan dengan yang diberi jagung atau 30\% dedak. Namun, kerabang telur ayam yang diberi pakan $30 \%$ dedak lebih tebal dari ayam yang diberi jagung atau BIS. Disimpulkan bahwa penambahan multi enzim BS4 dalam ransum cukup efektip meningkatkan performan ayam petelur.
\end{abstract}

Kata Kunci: Enzim BS4, Bungkil Inti Sawit, Dedak, Produksi Telur, Kualitas Telur

\begin{abstract}
Sinurat AP, Purwadaria T, Haryati T. 2016. Effectivity of BS4 enzyme complex on the performance of laying hens fed with different ingredients. JITV 21(1): 1-8. DOI: http://dx.doi.org/10.14334/jitv.v21i1.1389

An experiment was carried out to evaluate the effectivity of an enzyme complex produced by Eupenicilium javanicum BS4 on the performance of laying hens fed with different feed ingredients. Three diets were formulated with similar nutrients (protein, $\mathrm{ME}$, digestible amino acids, $\mathrm{Ca}$ and available $\mathrm{P}$ ) value to meet the nutrient requirement of laying hens. Diets were formulated based on maize, palm kernel cake (PKC) or rice bran. The diets were either supplemented or not with BS4 enzyme complex and fed to Isa Brown pullet from 19 to 37 weeks old. Each diet was fed to 24 birds and the performances were recorded. Data were analysed statistically with 2 X 3 factorial design with six replicates. Results showed that supplementation of BS4 enzyme into laying hens diet did not influence body weight change, feed intake, mortalities, egg weight and egg shell thickness but significantly increased egg production $(\mathrm{P}<0.05)$ and the FCR $(\mathrm{P}<0.01)$ in any feedstuff tested. It also improved egg yolk color score on diet contained $20 \%$ PKC. Laying hens fed $20 \%$ PKC produced more eggs than those fed maize or rice bran. The egg shell of laying hens fed rice bran were thicker than those fed with maize or PKC. It is concluded that BS4 enzyme complex is effective when supplemented into laying hens diet.
\end{abstract}

Key Words: BS4 Enzyme, Palm Kernel Cake, Rice Bran, Egg Production, Egg Quality

\section{INTRODUCTION}

Exogenous enzymes are widely used as feed additives in poultry diet nowadays. Although some enzymes such as amylase, are produced naturally for digestion of feed in the gastro-intestinal tract of poultry, supplementation of enzymes are meant to complement the endogenous enzymes to maximize nutrients utilization from feed, hence improve the feed efficiency.

Some feed ingredients were known to contain antinutritional factors which caused poor digestibility for monogastric animal. Two feed ingredients which are produced abundantly in Indonesia and commonly included in poultry diet, i.e., rice bran and palm kernel cake (PKC) also contain some anti-nutritional factors. Rice bran contains high crude fibre $(13.0 \%)$ which 
consists of cellulose, hemicellulose and lignin that are poorly digested by poutry (Gallinger et al. 2004; Batal $\&$ Dale 2012). According to Sundu et al. (2006) PKC contains $21-23 \%$ crude fibre. In more detail, Knudsen (1997) showed that PKC contains high (42\%) nonstarch polysaccharides (NSPs) in which, 33.6\% was insoluble NSPs. The high NSPs in the diet is considered as antinutritional factors since it can have negative effects on the digestibility and rate of absorption of carbohydrates, fat and protein or amino acids in poultry (Choct et al. 2010).

Inclusion of more than $10 \%$ rice bran in broiler diets (Gallinger et al. 2004) or laying hens diet (Samli et al. 2006) or more than $20 \%$ in laying quail diet (Abeyrathna et al. 2014) have shown significant reduction on their performances. Chong et al. (2008) reported that inclusion of $12.5 \%$ PKC in the diet significantly impaired the feed convertion ratio of laying hens and inclusion of $25 \%$ PKC impaired the FCR and eggs size, although the level of egg production was not affected. Sinurat et al. (2011) also showed that inclusion of $20 \%$ PKC in the diet, slightly reduced the egg production of laying hens.

Supplementation of exogenous enzyme, especially carbohydrases into poultry diet have been reported successfully to degrade NSPs in poultry diet and the effect of enzyme supplementation is more obvious when cereal with poor digestibility is present in the diet (Bedford 2000). Altough supplementation of enzymes also capable of improving the performance and intestinal physiological parameters of laying hens fed with high digestible feedstuffs such as corn-soy.

An enzyme complex, produced by Eupenicilium javanicum BS4 has been developed in our laboratory. The enzyme was aimed to improve nutrients digestibility of local feedstuffs with low quality such as palm oil by products (palm oil sludge and palm kernel cake). The enzyme was produced by cultivating Eupenicillium javanicum on coconut meal and consist of $\beta$-mannanase, CMCase (cellulase), $\beta$-mannosidase, $\beta$-glucosidase and $\alpha$-galactosidase (Haryati et al. 1997) which effectively digest cellulose and hemicellulose in palm kernel cake and palm sludge (Purwadaria et al. 2003). The effectivity of the enzyme to improve, metabolisable energy, dry matter and protein digestibilities of palm oil sludge (Sinurat et al. 2008; Pasaribu et al. 2009) and palm kernel cake (Sinurat et al. 2013) have been reported. The present study was designed to test the effectivity of the enzyme (BS4 enzyme) in improving the performance of laying hens when the feed was formulated to consist different feedstuffs, generally known to have low (maize) or high (PKC and rice bran) anti-nutritional levels.

\section{MATERIALS AND METHODS}

Three (3) diets consist of feedstuffs which are known to have different ANFs level, i.e., maize (low ANFs level), $30 \%$ rice bran (high ANFs level) and 20\% PKC (high ANFs level) were formulated with similar nutrient values (iso- ME, Iso- protein and digestible amino acids) to meet the nutrient requirement of laying hens. The nutrient contents of the diet were: $17 \%$ crude protein, $2750 \mathrm{kcal} / \mathrm{kg}$ ME, $3.9 \%$ calsium (Ca), $0.38 \%$ available phosphorous (Av. P), $0.740 \%$ digestible lysine, $0.440 \%$ digestible methionine, $0.635 \%$ digestible metionine + cystine, $0.160 \%$ digestible tryptophan and $0.523 \%$ digestible threonine. The formula and the composition of the diets are presented in Table 1. Each diet was either supplemented or not with BS4 enzyme. The enzyme was produced by Eupenicillium javanicum using coconut cake as substrate (Rakhmani et al. 2015). The level of enzyme supplemented was based on the results of previous experiment, i.e., $150 \mathrm{Unit} / \mathrm{kg}$ substrate.

One hundred and fourty four (144) Isa brown pullets, aged 16 weeks were allocated randomly, reared in individual wire cages and fed similar diet (pre-lay diet) for three (3) weeks. Each four (4) birds were provided with one feeder and therefore considered as one replicate. The birds were then fed with experimental diets from age 19 weeks to the end of experiment ( 37 weeks). Each treatment was fed to 24 hens (6 replicates with 4 birds/replicate). The production parameters were start measured a week later (age 20 weeks) for the next 18 weeks. Variables measured were body weight changes, feed intake, henday egg production, feed convertion ratio (calculated by dividing $g$ feed intake by $g$ egg produced) and egg quality (egg shell thickness and yolk color score). Body weight changes were measured by weighing the birds before and after the trial. Feed intakes were measured weekly. Eggs produced were collected and weighed daily. After 10 weeks treatment (birds aged 29 weeks), the egg quality were measured. All data were subject to analyses of variance in a $2 \times 3$ factorial design, i.e., 2 levels of enzyme supplementation (with or without enzyme supplementation) X 3 feedstuffs inclusion in the diet (maize, PKC and rice bran). The comparisons between treatment means were calculated by Duncan's multiple range test when the ANOVA was significant or $\mathrm{P}<0.05$. 
Sinurat et al. Effectivity of BS4 enzyme complex on the performance of laying hens fed with different ingredients

Table 1. Composition of experimental diets with different kind of feedstuffs inclusion

\begin{tabular}{|c|c|c|c|}
\hline \multirow{2}{*}{ Feed ingredients } & \multicolumn{3}{|c|}{ Source of ANFs } \\
\hline & Maize & Palm kernel cake & Rice bran \\
\hline Rice bran & 0 & 0 & 30 \\
\hline Palm kernel cake & 0 & 20 & 0 \\
\hline Maize & 62.58 & 45.32 & 36.40 \\
\hline Soybean meal & 22.91 & 9.23 & 12.15 \\
\hline Meat and bone meal 50 & 0.78 & 5.7 & 4.87 \\
\hline Corn gluten meal 60 & 2.5 & 6.5 & 5 \\
\hline Limestone & 9.39 & 8.55 & 8.78 \\
\hline Cooking oil & 0 & 3.75 & 1.89 \\
\hline DL-methionine & 0.17 & 0.16 & 0.19 \\
\hline L-lysine & 0 & 0.23 & 0.17 \\
\hline L-threonine & 0 & 0.01 & 0 \\
\hline Sodium bicarbonate & 0.1 & 0.1 & 0.1 \\
\hline Salt & 0.25 & 0.25 & 0.25 \\
\hline Vitamin premix & 0.03 & 0.025 & 0.025 \\
\hline Mineral premix & 0.05 & 0.05 & 0.05 \\
\hline Mono calcium phosphate (MCP) & 1.15 & 0 & 0 \\
\hline Choline chloride & 0.09 & 0.09 & 0.09 \\
\hline Tryptophan & 0 & 0.04 & 0.04 \\
\hline Total & 100 & 100 & 100 \\
\hline \multicolumn{4}{|l|}{ Nutrient contents } \\
\hline Dry matter $(\%)$ & 89.8 & 90.1 & 89.7 \\
\hline Crude fibre (\%) & 2.48 & 4.64 & 5.46 \\
\hline Metabolisable Energy (ME), kcal/kg & 2750 & 2744 & 2750 \\
\hline Crude Protein $(\%)$ & 17.70 & 17.70 & 17.70 \\
\hline Calcium (Ca) (\%) & 3.90 & 3.90 & 3.90 \\
\hline Available phosphorous (Av. P) (\%) & 0.38 & 0.38 & 0.38 \\
\hline Digestible lysine (\%) & 0.740 & 0.740 & 0.740 \\
\hline Digestible methionine (\%) & 0.440 & 0.442 & 0.438 \\
\hline Digestible methionine + Cystine (\%) & 0.635 & 0.630 & 0.630 \\
\hline Digestible tryptophan (\%) & 0.160 & 0.160 & 0.160 \\
\hline Digestible threonine (\%) & 0.523 & 0.523 & 0.523 \\
\hline
\end{tabular}

\section{RESULT AND DISCUSSION}

The effect of feeding different feedstuffs and enzyme supplementation on the performance of the laying hens are presented in Table 2. Results of analysis of variance did not show any significant $(P>0.05)$ effect of interaction between feedstuffs $(\mathrm{F})$ and enzyme supplementation (E) on the performance parameters (body weight changes, feed intake, HD egg production, egg weight and feed convertion ratio or FCR) during 
the 18 weeks of trial. Therefore the performance data are presented only to show the main effects of the treatment. Lack of significant interactions effect between $\mathrm{E} \times \mathrm{F}$ means that the effect of enzyme supplementation is applicable to all feedstuffs (maize, PKC and rice bran) used in this experiment. The mortality of the birds during the 18 weeks trial was very few (only 2 birds). The mortality was not considered as the effect of the treatments and therefore was not analysed statistically.

Supplementation of BS4 enzyme complex did not significantly $(\mathrm{P}>0.05)$ affect body weight changes, feed intake and egg weight, but significantly $(\mathrm{P}<0.05)$ influenced the HD egg production and feed convertion ratio (FCR) of laying hens (Table 2). Although the body weight gain is not the main output of laying hens, the measurement of body weigh changes is important as an indication of nutrients adequacy for the hens. The result showed that the BS4 enzyme supplementation did not cause nutrients imbalance in the laying hens diet. This is also supported by the feed intake data which showed no effect due to enzyme supplementation. The BS4 enzyme has been shown to increase the metabolisable enery (ME) but also the protein digestibility of PKC (Sinurat et al. 2011; Sinurat et al. 2013) and the amino acids digestibility of fermented-PKC.

Supplementation of the BS4 enzyme increased hen day egg productions significantly $(\mathrm{P}<0.05)$. Since the enzyme supplementation did not affect the feed intake, the increase in HD egg production (from $87.26 \%$ to $90.03 \%$ ) could be the effect of improvement in overall nutrients (energy, protein and amino acids) utilization by the hens as reported previously (Sinurat et al. 2011; Sinurat et al. 2013). As a result, the BS4 enzyme showed a significant $(\mathrm{P}<0.01)$ improvement in the feed efficiency or FCR. Chong et al. (2008) reported that commercial enzyme supplementation did not show improvement in egg production of laying hens fed PKC diet, but improve the FCR. Different kind and activities of enzyme used in both studies explained this discrepancy.

Although the mortalities of hens fed diet without enzyme was higher $(2.7 \%)$ than those fed enzyme diet $(0 \%)$. It is not considered as the effect of enzyme supplementation. Mortalities about 2\% during the period of the experiment (age 19 to 37 weeks old) are common for Isa brown laying hens (Hendrix Genetics 2007).

Supplementing exogenous enzymes into poultry diet have been reported by many authors in order to minimize the ANFs in poultry diet (Ravindran 2013). Based on some researches finding, Ravindran (2013) suggested that multiple enzymes may give a better results in improving nutrients utilization in poultry diet as compared to single enzyme. The presence of multi enzyme (more than one enzyme) may give additive or synergistic effect on nutrient utilization and animal performances. Saenphoom et al. (2013) reported that enzyme treatment effectively hydlrolyzed the fibre components of PKC and increase the TME of PKC in broilers.

As shown in Table 2, the body weight changes of laying hens were all positive or all birds gained some weight. The body weight changes were neither affected $(\mathrm{P}>0.05)$ by inclusion of different feedstuffs nor by enzyme supplementation. Body weight gain is not the main output of laying hens. However, body weigh changes can be a reflection of nutrients imbalance in the diet. Imbalances of dietary amino acids (methionine and cystine) have been reported to have a quadratic effect on body weight gain of laying hens (Narvaez-Solarte et al. 2005). Similar body weight changes in this experiment showed that inclusion of different feedstuffs and supplementation of BS4 enzyme did not affect the amino acids balance in the diet. This might be due to diet formulation applied in this experiment, i.e., based on digestible amino acids rather than on total amino acids.

The weekly egg production of laying hens for each treatment and comparison with the standard is provided in Figure 1. The rate of egg production was normal, when compared to Isa brown standard performance. In general, the egg production pattern and the average HD egg production of laying hens in this experiment was similar to the standard of Isa brown hens. The average HD egg production during the same period (age 20 to 37 weeks) according to (Hendrix Genetics 2007) was $88.6 \%$.

Inclusion of $20 \% \mathrm{PKC}$ in laying hens diet showed significantly $(\mathrm{P}<0.05)$ higher hen-day egg production as compared to inclusion of maize or rice bran, although all diets were formulated to have similar nutrient values. Similar finding was also reported by (Sinurat et al. 2011) when 5\% PKC but not $20 \%$ PKC included in the diet. Zanu et al. (2012) also reported an improvement in HD egg production when $5 \%$ or $10 \%$ $\mathrm{PKC}$ was included in laying hens diet. It is possible that inclusion of PKC in the diet has contributed some prebiotic that improve the health of gastro intestinal tract of the hens, improve nutrients absorbtion and and subsequently increase the egg production. PKC is known as a good source of $\beta$-mannan or its hydrolysed product oligomannan which can be functioned as prebiotics (Utami et al. 2013; Jahromi et al. 2016) which may improve the immune system of the birds. Inclusion of $20 \%$ PKC in broiler's diet has been reported to be as effective as commercial prebiotic in reducing intestinal bacteria (Escherichia coli) populations (Navidshad et al. 2015). Jahromi et al. (2016) also reported that supplementation of oligosaccharide (1 $\mathrm{g} / \mathrm{kg}$ diet) extracted from PKC increased the populations of beneficial bacteria 
Sinurat et al. Effectivity of BS4 enzyme complex on the performance of laying hens fed with different ingredients

Table 2. Production performance of laying hens as affected by feeding different feedstuffs and enzyme supplementation

\begin{tabular}{|c|c|c|c|c|c|c|}
\hline Feedstuff & $\begin{array}{l}\text { Body weight change, } \\
\text { (g/bird) }\end{array}$ & $\begin{array}{c}\text { Egg production } \\
\% \mathrm{HD}\end{array}$ & $\begin{array}{l}\text { Egg weight } \\
(\mathrm{g})\end{array}$ & $\begin{array}{l}\text { Feed intake } \\
(\mathrm{g} / \mathrm{d})\end{array}$ & FCR & $\begin{array}{c}\text { Mortality } \\
(\%)\end{array}$ \\
\hline \multicolumn{7}{|c|}{ Effect of different feedstuffs } \\
\hline Maize & 285.3 & $86.77^{\mathrm{a}}$ & 56.50 & $114.2^{\mathrm{a}}$ & 2.424 & 0 \\
\hline Palm Kernel Cake & 264.3 & $91.43^{\mathrm{b}}$ & 55.99 & $117.4^{\mathrm{b}}$ & 2.326 & 2.1 \\
\hline Rice Bran & 294.1 & $87.73^{\mathrm{a}}$ & 55.89 & $113.1^{\mathrm{a}}$ & 2.408 & 2.1 \\
\hline \multicolumn{7}{|c|}{ Effect of enzyme supplementation } \\
\hline - Enzyme* & 290.6 & $87.26^{\mathrm{a}}$ & 56.13 & 114.7 & $2.453^{\mathrm{b}}$ & 2.7 \\
\hline+ Enzyme* & 271.8 & $90.03^{\mathrm{b}}$ & 56.12 & 115.1 & $2.319^{\mathrm{a}}$ & 0 \\
\hline \multicolumn{7}{|c|}{ Level of Significance (P) } \\
\hline Feedstuff (F) & 0.647 & 0.009 & 0.601 & 0.001 & 0.147 & n.a** \\
\hline Enzyme (E) & 0.485 & 0.028 & 0.078 & 0.672 & 0.004 & n.a \\
\hline$E \times F$ & 0.940 & 0.515 & 0.667 & 0.661 & 0.221 & n.a \\
\hline
\end{tabular}

* + means enzyme supplemented; - means no enzyme supplemented

** n.a = not analysed statistically

Different superscript in the same column and treatment means significantly different $(\mathrm{P}<0.05)$

(Lactobacillus, Bifidobacterium and Enterococcus) and suppressed the populations of pathogenic (E. coli and Enterobacter) bacteria in the cecum of broiler chickens.

Feed intake of laying hens was significantly $(\mathrm{P}<0.01)$ affected by inclusion of different feedingstuff in the diet. The feed contained PKC were consumed more than those contained maize and rice bran. Chong et al. (2008) also reported an increase in feed intake when $12.5 \%$ or $25 \%$ PKC were included in the diet of of laying hens. However, this was not found by Sinurat et al. (2011) and Zanu et al. (2012). The incresase in the egg production as described earlier could be speculated as the effect of the increase in feed intake, since the feed convertion ratio (FCR) was not significantly $(\mathrm{P}>0.05)$ affected by inclusion of different feedstuff in the diet. It is commonly known that feed intake in poultry is dominantly controlled by energy level in the diet. Since all diet in this experiment was formulated iso- energy, the mechanism of feed intake increases in this case is not clearly understood. Whether the presence of prebiotic or oligosaccharide contributed by PKC in the diet stimulate the feed intake or not, needs to be investigated further. Navidshad et al. (2015) showed a slightly (2\%) increase in feed intake of broilers when $20 \%$ of PKC was included in the diet.

The inclusion of different feedstuff in the diet did not significantly $(\mathrm{P}>0.05)$ affect the egg weight, FCR and mortalities. Feedstuffs contain high ANFs (crude fibre or NSPs) are included in the poultry diet in limited amount. In general, feed mills in Indonesia only included maximum of $20 \%$ rice bran and $5 \% \mathrm{PKC}$ in laying hens diet. The present study showed that inclusion of $30 \%$ rice bran or $20 \%$ PKC did not impair the productivity of laying hens. Other reports showed that inclusion of 10\% (Sinurat et al. 2011; Zanu et al. 2012), 20\% (Perez et al. 2000), or 25\% PKC (Chong et al. 2008) in the diet can support a good productivity performance of laying hens. Therefore, in countries with high production of rice bran and or PKC such as Indonesia, it is encouraged to use these feedstuffs as it may reduce the cost of production.

The effect of inclusion of different feedstuffs and enzyme supplementation on the egg quality is presented in Tabel 3. The egg shell thickness was significantly $(\mathrm{P}<0.01)$ affected by inclusion of different feedstuffs but not by enzyme supplementation in the diet nor by the interaction between the two factors. Inclusion of rice bran significantly produced thicker egg shell than others. According to Zita et al. (2009) egg shell thickness of Isa brown was 37-38 $\mu \mathrm{m}$. Nutritionally, egg shell thickness were mainly influenced by calcium (Ca), available phosphorus (Av. P) and D vitamin. All diets have been formulated to to contain similar levels of those nutrients (Table 1). Rice bran is known to contain high $\mathrm{P}$ levels but very low Av. P. Improper balance between $\mathrm{Ca}$ and Av. P may affect the egg shell thickness. Although all diets were formulated to contain similar available $\mathrm{P}(0.38 \%)$, it might be that the calculated value of the Av. P of rice bran was over estimated and the diet with rice bran was lower than expected. Abubakar et al. (2007) also reported an increase in egg shell thickness of laying hens when $30 \%$ rice bran was included in the diet as compared to the control (without rice bran).

As shown in Table 3, the egg yolk color score was significantly $(\mathrm{P}<0.01)$ affected by the interaction 
between feeding different feedstuffs (F) and enzyme supplementation (E). Statistical analyses revealed that supplementation of BS4 enzyme in maize- feed or rice bran did not affect the egg yolk color significantly $(\mathrm{P}>0.05)$. However, enzyme supplementation in PKCfeed increased the egg yolk color score significantly $(\mathrm{P}<0.05)$. Inclusion of $\mathrm{PKC}$ in the diet without enzyme supplementation, significantly $(\mathrm{P}<0.05)$ produced higher egg yolk color score as compared to others. Previous study also reported an increase in egg yolk color score when PKC (Zanu et al. 2012), or enzyme supplemented fermented-PKC was included in laying hens diet.

\section{CONCLUSION}

The results of this study conclude that BS4 enzyme is effective in improving egg production and feed efficiency (FCR) when supplemented into feed of laying hens contains either maize, $30 \%$ rice bran and $20 \%$ palm kernel cake (PKC). Supplementation of BS4 enzyme into laying hens diet did not influence the body weight change, feed intake, mortalities, egg weight and egg shell thickness. Laying hens fed diet with $20 \%$ PKC produced more eggs than those fed diet with maize or rice bran and supplementation of BS4 enzyme into the diet improved the egg yolk color score fed the PKC diet but no effect on maize or rice bran diet.

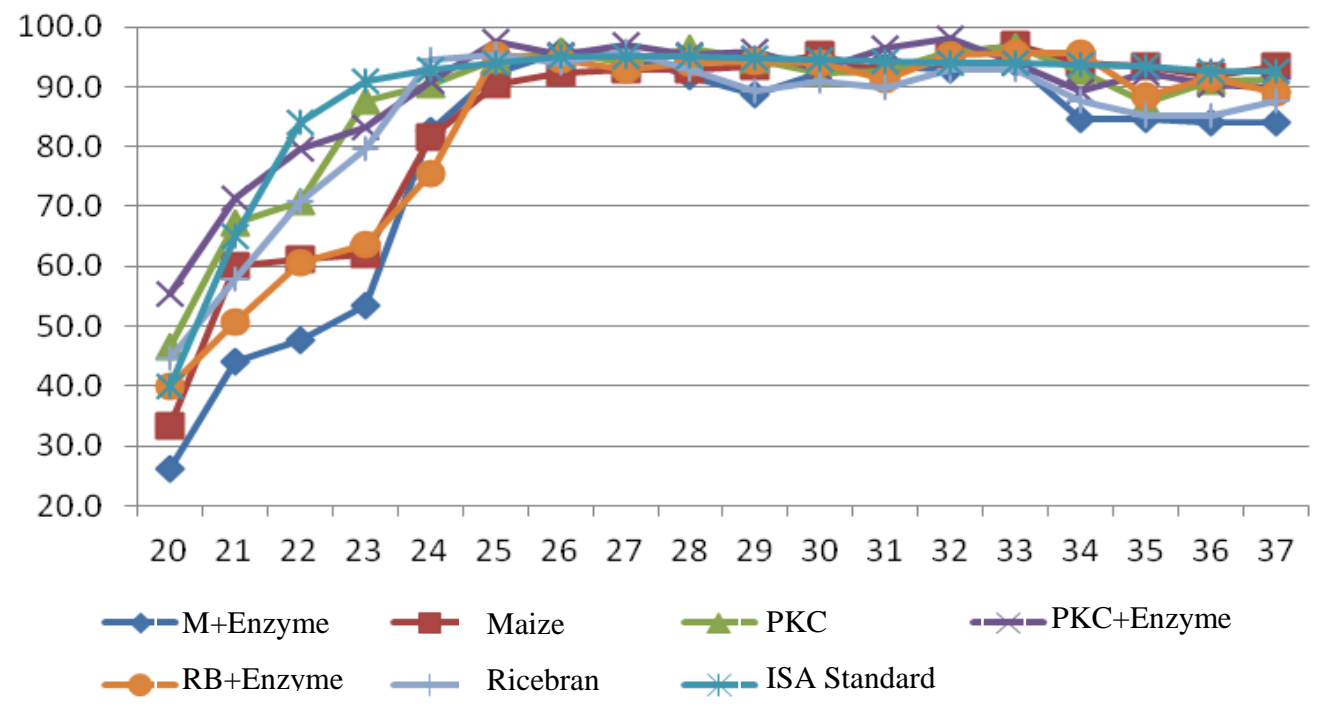

Figure 1. Weekly egg production of laying hens fed with different feedstuffs and enzyme supplementation.

Table 3. Egg quality of laying hens as affected by feeding different feedstuffs and enzyme supplementation

\begin{tabular}{|c|c|c|c|}
\hline Feedstuff & Enzyme** & Egg shell thickness*, $\mu \mathrm{m}$ & Yolk color score* \\
\hline Maize & - & $45.3^{\mathrm{a}}$ & $4.6^{\mathrm{d}}$ \\
\hline Maize & + & $45.4^{\mathrm{a}}$ & $4.8^{\mathrm{cd}}$ \\
\hline Palm kernel cake & - & $47.2^{\mathrm{a}}$ & $5.4^{\mathrm{b}}$ \\
\hline Palm kernel cake & + & $46.4^{\mathrm{a}}$ & $6.2^{\mathrm{a}}$ \\
\hline Rice bran & - & $48.7^{\mathrm{b}}$ & $5.0^{\mathrm{c}}$ \\
\hline Rice bran & + & $47.9^{\mathrm{b}}$ & $4.8^{\mathrm{cd}}$ \\
\hline \multicolumn{4}{|c|}{ Level of significance $(\mathrm{P})$} \\
\hline Feedstuff (F) & & 0.008 & 0.001 \\
\hline Enzyme (E) & & 0.405 & 0.013 \\
\hline $\mathrm{F} \times \mathrm{E}$ & & 0.907 & 0.001 \\
\hline
\end{tabular}

* Values with different letters within the same column different significantly $(\mathrm{P}<0.05)$

$* *+\quad$ means enzyme supplemented; - means no enzyme supplemented 


\section{ACKNOWLEDGEMENT}

The authors appreciate all the technicians who helped to produce the enzyme and looking after the animal. Those were Mr Helmi Hamid, Mrs Emi Sujatmika, Mr Kadiran and Mr Agus.

\section{REFERENCES}

Abeyrathna HMWN, Atapattu NSBM, Gunawardane WWDA. 2014. Effects of the level of dietary rice bran with or without phytase on performance and egg parameters of laying Japanese quail. Trop Agric Res. 26:39-47.

Abubakar A, Tukur HM, Sekoni AA, Hassan WA. 2007. Performance and egg quality characteristics of laying birds fed diets containing rice bran with and without yeast supplementation. Asian J Anim Sci. 1:1-9.

Batal A, Dale N. 2012. Ingredient Analysis Table: 2011 Edition. Feedstuffs, 15 September 2010. http://fdsmagissues.feedstuffs.com [Internet]. [cited 2014 Aug 9]. Available from: http://fdsmagissues.feedstuffs.com.

Bedford MR. 2000. Mechanism of action and potential environmental benefits from the use of feed enzymes. Anim Feed Sci Technol. 53:145-155.

Choct M, Derrsjant-Li Y, McLeish J, Peisker M. 2010. Soy oligosaccharides and soluble Non-starch polysaccharides: A Review of digestion, nutritive and anti-nutritive effects in pigs and poultry. Asian-Aust J Anim Sci. 23:1386-1398.

Chong CH, Zulkifli I, Blair R. 2008. Effects of dietary inclusion of palm kernel cake and palm oil and enzyme supplementation on performance of laying hens. AsianAust J Anim Sci. 21:1053-1058.

Gallinger CI, Suarez DM, Irazusta A. 2004. Effects of rice bran inclusion on performance and bone mineralization in broiler chicks. J Appl Poult Res. 13:183-190.

Haryati T, Purwadaria T, Darma J, Tangendjaja B. 1997. Production of extracellular glycosidase by Eupenicillium javanicum and Aspergillus niger NRRL 337 on the coconut meal substrate. In: Proceeding Second Conf Agric Biotechnol. Jakarta (Indones): Indonesian Agency for Agricultural Research and Development. p. 517-522.

Hendrix Genetics. 2007. Performance of Isa Brown Final Product.

Jahromi MF, Liang JB, Abdullah N, Goh YM, Ebrahimi R, Shokryazdan P. 2016. Extraction and characterization of oligosaccharides from palm kernel cake as prebiotic. Bio Resour. 11:674-695.

Knudsen KEB. 1997. Carbohydrate and lignin contents of plant materials used in animal feeding. Anim Feed Sci Technol. 67:319-338.
Narvaez-Solarte W, Rostagno HS, Soares PR, Silva MA, Velasquez LFU. 2005. Nutritional requirements in methionine + Cystine for White- egg laying hens during the first cycle of production. Int J Poult Sci. 4:965-968.

Navidshad B, Liang JB, Jahromi MF, Akhlaghi A, Abdullah N. 2015. A comparison between a yeast cell wall extract (Bio-Mos $\left.{ }^{\circledR}\right)$ and palm kernel expeller as mannanoligosac-charides sources on the performance and ileal microbial population of broiler chickens. Ital J Anim Sci. 14:3452.

Pasaribu P, Sinurat AP, Purwadaria T, Ketaren PP. 2009. Peningkatan nilai gizi solid heavy phase sebagai pengganti jagung dalam pakan unggas. JITV. 14:167176.

Perez JF, Gernat AG, Murillo JG. 2000. The effect of different levels of palm kernel meal in layer diets. Poult Sci. 79:77-79.

Rakhmani SIW, Pangestu Y, Sinurat AP, Purwadaria T. 2015. Carbohydrate and protein digestion on palm kernal cake by Mannanase BS4 and papain cocktail enzymes. Indones J Anim Vet Sci. 20:268-274.

Ravindran V. 2013. Feed enzymes: The science, practice, and metabolic realities. J Appl Poult Res. 22:628-636.

Saenphoom P, Liang JB, Ho YW, Loh TC, Rosfarizan M. 2013. Effects of enzyme treated palm kernel expeller on metabolizable energy, growth performance, villus height and digesta viscosity in broiler chickens. AsianAust J Anim Sci. 26:537-544.

Samli HE, Senkoylu N, Akyurek H, Agma A. 2006. Using rice bran in laying hen diets. Cent Eur Agric. 7:135-140.

Sinurat AP, Purwadaria T, Bintang IAK, Pasaribu T, Manurung, B P Manurung N. 2008. Substitution of corn with enzymes treated palm oil sludge in laying hens diet. In: Procedings XXIII World's Poult Sci Congr. Brisbane (Australia)

Sinurat AP, Purwadaria T, Pasaribu T. 2013. Peningkatan nilai gizi bungkil inti sawit dengan pengurangan cangkang dan penambahan enzim. Indones J Anim Vet Sci. 18:34-41.

Sinurat AP, Purwadaria T, Pasaribu T, Ketaren PP. 2011. Performances of laying hens fed with enzyme supplemented palm kernel cake diets. In: Procedings 9th Asia Pacific Poult Conf. Taipeh (Taiwan).

Sundu B, Kumar A, Dingle J. 2006. Palm kernel meal in broiler diets: Effect on chicken performance and health. World Poult Sci J. 62:316-325.

Utami W, Meryandini A, Wiryawan KG. 2013. Characterization of bacterial mannanase for hydrolyzing palm kernel cake to produce manno-oligosaccharides prebiotics. Media Peternak. 36:192-196.

Zanu HK, Abangiba J, Arthur-Badoo W, Akparibo AD, Sam R. 2012. Laying chickens' response to various levels of palm kernel cake in diets. Int J Livest Prod. 3:12-16. 
Zita L, Tumova E, Stolc L. 2009. Effects of genotype, age and their interaction on egg quality in brown-egg laying hens. Acta Vet BRNO. 78:85-91. 